\title{
R. G. COLLINGWOOD’S OVERLAPPING IDEAS OF HISTORY
}

Christopher Fear

\section{ABSTRACT}

Does R. G. Collingwood's meta-philosophical theory that concepts in philosophy are organized as "scales of forms" apply to his own work on the nature of history? Or is there some inconsistency between Collingwood's work as a philosopher of history and as a theorist of philosophical method? This article surveys existing views among Collingwood specialists on the applicability of Collingwood's "scale of forms" thesis to his own philosophy of history, especially the accounts of Leon Goldstein and Lionel Rubinoff, and outlines the obvious objections to such an application. These objections however are found to be answerable. It is shown that Collingwood did indeed think the scale of forms thesis should apply to the philosophy of history, and even that he identified the "highest" form in history as a kind of scientific research or inquiry. But it is not demonstrated that Collingwood identified the "lower" forms explicitly. An account is then provided of the three distinct forms that can be identified in Collingwood's philosophy of history, and of the "critical points” by which (according to Collingwood's philosophical 
method) lower forms are negated and incorporated by higher forms. But it is also explained that these forms are not neatly coterminous with the stages in Western philosophical thinking about history as Collingwood narrates them in The Idea of History.

\section{KEYWORDS}

R. G. Collingwood - philosophy of history - meta-philosophy methodology - metaphysics - epistemology

"[T]he philosophy of history is nothing but the deliberate attempt to answer the question 'what is history?'”1

\section{THE SCALE OF FORMS THESIS}

According to R. G. Collingwood, there are various ways by which we can define what we mean by a word in nonphilosophical discussion. But in philosophical discussion, Collingwood thinks, where we attempt to deploy the special philosophical meaning of such words, ${ }^{2}$ we must specify our

${ }^{1}$ R. G. Collingwood, Essays in the Philosophy of History, ed. William Debbins (Austin: University of Texas Press, 1967), 126.

${ }^{2}$ R. G. Collingwood, An Essay on Philosophical Method [1933] (Oxford: Clarendon, 2005), 33-35. 
concepts "in a somewhat peculiar way." ${ }^{3}$ We employ what Collingwood calls a "scale of forms"4 to clarify concepts incrementally. The "members" of such a scale are so related that each embodies the "generic essence" of the concept in some way. ${ }^{5}$ Each higher term is a "different" but also a "more adequate embodiment of the generic essence". ${ }^{6}$ And "whenever the variable, increasing or decreasing, reaches certain points on the scale, one specific form disappears and is replaced by another": 7 these, Collingwood explains, are "critical points on a scale of degrees where a new specific form suddenly comes into being." ${ }^{8}$ The higher term "negates" the lower "as a false embodiment," but "at the same time reaffirms it ... as part and parcel of itself." ${ }^{9}$ So while each higher term reveals the lower to be the wrong way of specifying the whole concept, it also incorporates it as an element within this new whole. ${ }^{10}$ Lower forms are defective from the point of view of higher forms;

\footnotetext{
${ }^{3}$ Collingwood, Essay on Philosophical Method, 57.

${ }^{4}$ Collingwood, Essay on Philosophical Method, 54-91.

${ }^{5}$ Collingwood, Essay on Philosophical Method, 57.

${ }^{6}$ Collingwood, Essay on Philosophical Method, 88.

${ }^{7}$ Collingwood, Essay on Philosophical Method, 57.

${ }^{8}$ Collingwood, Essay on Philosophical Method, 57.

${ }^{9}$ Collingwood, Essay on Philosophical Method, 88.

${ }^{10}$ Collingwood, Essay on Philosophical Method, 89.
} 
indeed they might even appear as “opposites”. ${ }^{11}$ Collingwood spends four pages of his Essay on Philosophical Method (1933) explaining that philosophers including Plato, Aristotle, Leibniz, Kant, and even Locke ${ }^{12}$ have defined their philosophical concepts in this way, and devotes thirty more pages to vindicating that method. Everywhere in philosophy, he writes, "the same rule holds good."13

But does this “meta-philosophical” rule, or rule of philosophical method-which is supposed to hold good everywhere-apply to Collingwood's own philosophy of history? Certainly several of his readers have discerned different ideas of history in his writings. Alan Donagan finds in Collingwood's essay, "Historical Evidence”, the "three forms of historical thinking which have been practised since the Renaissance.”14 More recently, Giuseppina D’Oro has identified a "factual” conception of history, a "formal"

${ }^{11}$ Collingwood, Essay on Philosophical Method, 84.

${ }^{12}$ Collingwood, Essay on Philosophical Method, 57-61.

${ }^{13}$ Collingwood, Essay on Philosophical Method, 44; see also R. G. Collingwood, The New Leviathan: or Man, Society, Civilization and Barbarism [1942] revised edition, ed. David Boucher (Oxford: Clarendon, 1992), 70.

${ }^{14}$ Alan Donagan, The Later Philosophy of R. G. Collingwood (Oxford: Clarendon Press, 1962), 177-182. 
conception, and a "substantive" conception. ${ }^{15}$ Other

Collingwood scholars have sought to elucidate ostensibly

unitary accounts of "history as" in full-length studies: Jan van

der Dussen’s History as a Science (1981), ${ }^{16}$ for example; W. H.

Dray’s History as Re-Enactment (1995); ${ }^{17}$ and Stein Helgeby's

Action as History (2004). ${ }^{18}$

Since Collingwood's plan for his Essays, Principles, and Ideas books was never completed, there is some speculation concerning the fit of these ostensibly distinct conceptions of history with the scale of forms thesis. James Connelly has proposed that the two volumes of Philosophical Essays (of which An Essay on Philosophical Method is the first) “would have elucidated both the approach and subject matter of ... The Principles of History”, ${ }^{19}$ while The Idea of

15 Giuseppina D’Oro, “On Collingwood's Conceptions of History,” Collingwood and British Idealism Studies 7 (2000), 45-69.

${ }^{16}$ J. W. van der Dussen, History as a Science: The Philosophy of R. G. Collingwood (Boston: Martinus Nijhoff, 1981).

${ }^{17}$ W. H. Dray, History as Re-Enactment: R. G. Collingwood's Idea of History [1995] (Oxford: Clarendon Press, 2001).

${ }^{18}$ Stein Helgeby, Action as History: The Historical Thought of R. G. Collingwood (Exeter: Imprint Academic, 2004)

19 James Connelly, Metaphysics, Method and Politics: The Political Philosophy of R.G. Collingwood (Exeter: Imprint 
History was intended to be an essay "of historical metaphysics displaying an historical scale of forms.”20 So as Connelly sees it, The Principles of History and The Idea of History would have comprised "a concrete application [to history] of the view of philosophy developed in the two Essays.” ${ }^{21}$ Other readers, such as Lionel Rubinoff and Leon Goldstein, have even attempted to construct content for that sort of application, identifying different ideas of history in Collingwood's thinking and explicitly sketching a scale of forms arrangement for them..$^{22}$

\section{OBJECTIONS}

But this application of the scale of forms thesis to Collingwood's writings on history—which for ease I will call the "application" theory—is open to several objections. First, Collingwood never says, in The Idea of History or in The Principles of History, that he is following his scale of forms Academic, 2003), 14.

${ }^{20}$ Connelly, 14; see also 76.

${ }^{21}$ Connelly, 14-15.

22 See Lionel Rubinoff, Collingwood and the Reform of Metaphysics: A Study in the Philosophy of Mind (University of Toronto Press, 1970), 132-49; Leon J. Goldstein, “The Idea of History as a Scale of Forms," History and Theory 29, no. 4 (Dec 1990), 42-50. 
method. Although his work contains plenty of statements beginning "history is", and "history means”, none of the definitions that follow is ever identified as a "form" of a concept. History is almost never explicitly defined at all, and where the term "the definition of history” does appear, it is only in the context of prolegomena or an introduction to a lecture series. ${ }^{23}$ Certainly different accounts of history are described as improving upon one another in The Idea of History, but never as overlapping, or as part of a scale. Indeed the formal language of the Essays-An Essay on Philosophical Method and An Essay on Metaphysics_-is hardly used.

Further, there is no obvious evidence that Collingwood planned to use a scale of forms in his unfinished The Principles of History. ${ }^{24}$ Indeed, although he intended to discuss "survivals

${ }^{23}$ R. G. Collingwood, The Idea of History [1946]: with lectures 1926-1928, ed. Jan van der Dussen (Oxford University Press, 1993), 9.

${ }^{24}$ See "Notes on Historiography," in R. G. Collingwood, The Principles of History and other writings in philosophy of history [1999] ed. W. H. Dray and W. J. van der Dussen (Oxford, 2001), 235-250, 245-246. See however also van der Dussen's illuminating discussion of the differences between Collingwood's scheme for The Principles of History, and the papers that were recovered in 1995: Collingwood, Principles of History, xviii-xx. 
of the original generalized sense [of history] in modern uses”, The Principles of History as Collingwood planned it was only to deal "with the specialized sense" — that is, with "history as a special science". ${ }^{25}$ All of this is perhaps surprising, given the high regard in which Collingwood still held his Essay on Philosophical Method as he worked on his philosophy of history in the later 1930 s. $^{26}$

Further still, this “application” theory assumes (1) that, for Collingwood, history can be treated as a "generic concept”27 in the first place; and (2) that his work on it can be interpreted as a process of attempting to specify that concept. ${ }^{28}$ In fact in Speculum Mentis history is described not as a concept, but as "a form of thought”, ${ }^{29}$ and as “a specific form of experience”, ${ }^{30}$

If these objections stand, and the scale of forms thesis

${ }^{25}$ Collingwood, Principles of History, 245.

26 See R. G. Collingwood, An Autobiography and other writings: with essays on Collingwood's life and work, ed. David Boucher and Teresa Smith (Oxford: Oxford University Press, 2013), 117-118.

${ }^{27}$ Collingwood, Essay on Philosophical Method, 57.

${ }^{28}$ See Collingwood, Essay on Philosophical Method, 92-103, and Collingwood, The Idea of History, 9.

${ }^{29}$ R. G. Collingwood, Speculum Mentis, or The Map of Knowledge [1924] (Oxford: Clarendon Press, 1963), 203.

${ }^{30}$ Collingwood, Speculum Mentis, 205. 
should not be sought in Collingwood's philosophy of history, or applied to it, then there would seem to be significant inconsistency between Collingwood's writings on his two main preoccupations, the nature of history, and the nature of philosophy. One or more of these verdicts would seem to follow:

1. If Collingwood's philosophy of history is good, then his scale of forms theory is wrong, or at least he did not put much stock in it, because he managed to make advances in philosophical thinking on history without following his own method.

2. Collingwood abandoned the scale of forms theory between publishing it (1933) and developing his thinking on history in the later 1930s. And indeed as Teresa Smith has rightly pointed out, ${ }^{31}$ Collingwood's rapprochements between history and philosophy, and between theory and practice, were his priority in the later 1930s and early 40s. ${ }^{32}$ In that later work,

${ }^{31}$ In conversation at the PSA British Idealism Specialist Group Annual Conference, Gregynog Hall, UK, $18^{\text {th }}-20^{\text {th }}$ December, 2017.

${ }^{32}$ Collingwood, Autobiography, 147-167. See also Christopher Fear, “'Was he right?’ R. G. Collingwood’s Rapprochement between Philosophy and History”, Journal of the Philosophy of History 11 (2017), 408-424. 
Collingwood is trying to demonstrate the importance of history to philosophy and practice. It is just not on his agenda at this time to vindicate any further his earlier scale of forms thesis.

But, although each of these possible verdicts leaves Collingwood's achievements in philosophy of history unchallenged, each implicitly undermines an indispensable thesis of his Essay on Philosophical Method. Conversely, if Collingwood's scale of forms theory is sound, then its absence from his philosophy of history would lead to one of two other possible verdicts:

3. Collingwood's philosophy of history is not as good as it should have been, because it attempts to shortcut a valuable contribution he had already made to philosophical method. Indeed the argument that was on his agenda, concerning a rapprochement between history and philosophy, is also weakened if the idea of history that Collingwood is deploying is not specified by adequate philosophical method.

4. For some reason, Collingwood thinks that the scale of forms arrangement does not apply to philosophy of history—perhaps because, as above, he does not regard history as a true "generic concept", or because he does not consider it specifiable, or because he does not think it has a "generic essence," or so forth. 
THESIS: HISTORY AS A SCALE OF FORMS

But even though it was not Collingwood's priority, and even though there is no obvious indication that he tried deliberately to follow his own method, or that he considered history a "generic concept", there is some evidence that Collingwood nevertheless did think that the scale of forms theory should apply to history. In a note concerning the question whether nature has a history, he writes:

I seem driven back to the scale of forms (is this another ready-made formula? No, not in any bad sense, for it was made to fit exactly such cases as this). Existence is history, but the scale of existences is a scale in which the historical character is at first rudimentary and then gradually emerges. It will be necessary to trace the stages of this emergence. / History in the fullest sense—-historian's history—is a thing whose nature and methods I know well ... But in order that there should be history in this highest sense there must first be history in a vaguer and lower sense. ${ }^{33}$

${ }^{33}$ Collingwood, Principles of History, 126-127. 
Collingwood thinks, then, that the scale of forms thesis should apply to philosophy of history. But does his own work actually comply? It seems to me that the only way to answer this question of a scale of forms for Collingwood's philosophy of history is to identify these "vaguer and lower" forms, and to establish whether they relate to each other in the way that Collingwood says they should.

\section{INQUIRY AND THE ASSERTION OF FACT}

Let us begin with the form of history that Collingwood explicitly identifies when he writes, to himself, that "History in the fullest sense - historian's history—is a thing whose nature and methods I know well." ${ }^{34}$ Now, as Jan van der Dussen has found, Collingwood begins to focus upon history in this sense more intensely from around the time of his 1925 essay, "The Nature and Aims of a Philosophy of History”, where he begins by mentioning "actual historians". ${ }^{35}$ History thenceforth is “a kind of research or inquiry”36_ “scientific”, ${ }^{37}$ albeit "a special

34 Collingwood, Principles of History, 126-127 (emphasis added).

${ }^{35}$ Van der Dussen, History as a Science, 28.

${ }^{36}$ Collingwood, Idea of History, 9.

37 Collingwood, Autobiography, 122; R. G. Collingwood, An Essay on Metaphysics [Oxford: Clarendon, 1940] (Mansfield Centre, Connecticut: Martino, 2014), 65; Principles of 
science" ${ }^{38}$ — in which questions are posed and answered by way of evidence and reasoning. For simplicity I will call this highest form of history “history as inquiry”. Collingwood's analysis of history as inquiry includes elements of the epistemological, methodological, and metaphysical (by Collingwood's definition of metaphysics). ${ }^{39}$ It explains how historians arrive at their goal of accurately re-enacted thoughts, ${ }^{40}$ how history affords selfknowledge, and why a rapprochement between history and philosophy must be achieved.

However, van der Dussen also argues that before 1925 Collingwood had a very different idea of the nature of history, which is reflected in his focus on the object of historical knowledge. Van der Dussen points to passages such as: "the historical consciousness asserts concrete fact”; “[history] does not come to the facts with a ready-made law in its hand and try to force them into it, throwing them away in disgust when they History, 7-8, 35; Idea of History, 269-270.

${ }^{38}$ Collingwood, Principles of History, 245.

${ }^{39}$ See Collingwood, An Essay on Metaphysics, 3-48.

${ }^{40}$ See Margit Hurup Nielsen, “Re-Enactment and Reconstruction in Collingwood's Philosophy of History,” History and Theory 20, no. 1 (Feb, 1981), 1-31; Karsten R. Stueber, “The Psychological Basis of Historical Explanation: Reenactment, Simulation, and the Fusion of Horizons,” History and Theory 41, no. 1 (Feb, 2002), 25-42. 
are too hard; it rejoices in their hardness and finds its satisfaction in their very diversity and uniqueness"; “The object of history is fact as such”; “An historian must state the facts as they happened"; and, "History is the knowledge of the infinite world of facts”. ${ }^{41}$

History for Collingwood before 1925 seems, on this account, not to refer to the thing that historians do, but to the object to which (or with which) they do it; not to characteristic processes, but to the objects dealt with. Thus, according to van der Dussen, Speculum Mentis (1924) paints a "plainly realistic picture of history," 42 which must have become regrettable to Collingwood after his 1925 conversion, and as his more sophisticated "idealist” or “anti-realist” account of history developed. "When Collingwood, having written this book, turned to the actual practice of the science of history," van der Dussen writes, "his treatment of this subject in Speculum Mentis — or better, the place he gave it in his system—must have been unsatisfactory to him too.”43

Van der Dussen's dating of Collingwood's more focused study of historical inquiry is well substantiated by his evidence. But it is not true that this earlier definition of history—which here I will call history as "the assertion of fact" and "fact as

\footnotetext{
${ }^{41}$ Collingwood, Speculum Mentis, 208, 210, 211, 216, 231.

${ }^{42}$ Van der Dussen, History as a Science, 25.

${ }^{43}$ Van der Dussen, History as a Science, 27.
} 
such" — is abandoned or contradicted from 1925/26 onward. It is true that there are passages in The Principles of History which might be presented as evidence that the earlier idea of history is abandoned. ${ }^{44}$ But there is also plenty of counterevidence in the same later work. Collingwood writes: "it is still permissible to describe the things that the historian wants to know as 'facts', for example the 'fact' that Aurelian reformed the Roman monetary system”, which “is asserted as a fact by economic historians ... as the conclusion of an argument based on analysis of numismatic evidence"; 45 "The objectivity of historical fact is this: that there was such a fact”; 46 “An historical cause is a fact or assembly of facts", ${ }^{47}$ and "To be real, for history, is to be a fact, i.e. objectivity is sought." ${ }^{\text {"48 }}$ It is true that after 1925/6 Collingwood attacks the notion that the

44 Including: "[To] pretend that the essential element in discovery is the 'apprehension of facts' ... is to undermine the foundations of science” (Principles of History, 38); “The plausibility of historical naturalism ... rested in its day on a supposed similarity between the 'facts' of history and the 'facts' of natural science.” Collingwood, Principles of History, 80.

${ }^{45}$ Collingwood, Principles of History, 81.

${ }^{46}$ Collingwood, Principles of History, 222.

${ }^{47}$ Collingwood, Principles of History, 12.

${ }^{48}$ Collingwood, Principles of History, 135. 
historian simply “observes" his facts ${ }^{49}$ — but he had never claimed otherwise. Indeed, his long-running critique of the doctrine that knowing makes no difference to the thing known is also in Speculum Mentis ${ }^{50}$ (where it is part of the "breakdown" of history, see below). ${ }^{51}$ So although Collingwood's later philosophy of history is, as van der Dussen says, largely about history as inquiry, he also continues to discuss the "object" of historical thought, and to identify it with a type of assertion, the assertion of individual things that really have happened, ${ }^{52}$ as he had in Speculum Mentis, where history is about "what happens and has happened, and that only". ${ }^{53}$ History as "the assertion of fact" is retained, then, in Collingwood's later thought as a lower form, but is supplemented by a later, “higher” form. Despite this, history as "the assertion of fact" or "fact as such" is crucial. It is for example an essential component of the idea of res gestae-the individual "deeds, actions done in the past" ${ }^{54}$ which the historian's assertions should be about. The survival of "the

49 Collingwood, Principles of History, 80-81; see also Collingwood, Idea of History, 66.

${ }^{50}$ Collingwood, Speculum Mentis, 237, 243-245.

${ }^{51}$ Collingwood, Speculum Mentis, 231-239.

${ }^{52}$ Collingwood, Principles of History, 221.

${ }^{53}$ Collingwood, Speculum Mentis, 217.

${ }^{54}$ Collingwood, Principles of History, 40. 
assertion of fact," or "fact as such", secures the individual rather than universal nature of the object of historical knowledge: facts rather than laws, and concrete ideas rather than a priori ideas. ${ }^{55}$ Those who insisted on this in nineteenthcentury German thought—-such as Ranke, Windelband, and Rickert—were defending history as an "idiographic” discipline distinct from the "nomothetic" sciences which are validated by the laws and predictions they offer. ${ }^{56}$ Collingwood may disapprove of the terminology, ${ }^{57}$ but he shares their view of historians who aspire to the methods and aims of natural science by "subordinating" individual facts to general laws. ${ }^{58}$ In

55 Collingwood, Idea of History, 72-73. That is the positive claim in Collingwood's attack on positivism and "Pigeonholing.” Collingwood, Principles of History, 19-21.

${ }^{56}$ See Georg G. Iggers, The German Conception of History: The National Tradition of Historical Thought from Herder to the Present (Middletown, Connecticut: Wesleyan University Press, 1983).

57 “This distinction he pompously baptized by saying that there were two kinds of science (Wissenschaft): nomothetic science, which is science in the common sense of the word, and idiographic science, which is history." Collingwood, Idea of History, 166.

${ }^{58}$ Collingwood, Principles of History, 78-79, 181-183; 246; and Collingwood (quoting Schopenhauer), Idea of History, 167. 
The Idea of History science presupposes history, just as it does in Speculum Mentis, precisely because history is the assertion of individual facts from which laws are an abstraction ${ }^{59}$-an assertion made not by a "scientific" (in this case meaning "nomothetic" or "positivistic") consciousness, but by an historical consciousness. ${ }^{60}$

\section{HISTORY AS PROCESS}

Alongside the two forms of history discussed by van der Dussen — history as inquiry, and history as "the assertion of fact"-there is however also a third form that appears in all of Collingwood's writings on history. I will call this form "history as process" for convenience, and because "process" is the term Collingwood generally prefers to metonyms such as "change” and "transition" - though it is important to note his insistence

${ }^{59}$ Collingwood, Speculum Mentis, 202, 218; Collingwood, Idea of History, 201.

${ }^{60}$ Collingwood, Speculum Mentis, 201-202. There is a potential terminological confusion however between what Collingwood means by "scientific" history in Speculum Mentis (216), where he means "positivistic," and what he means by it in his later writings, which is "systematic thinking.” See Collingwood, Autobiography, 25-26, 30-31; Collingwood, Idea of History, 269, 273; Collingwood, Essay on Metaphysics, 4. 
that history not be identified with process per se, ${ }^{61}$ but specifically with development. ${ }^{62}$

Process, as continuity and discontinuity, ${ }^{63}$ is a notable focus of Collingwood's analysis of Greco-Roman historiography; it is also the meaning of his identification of "What is historical" with "the transitory event", ${ }^{64}$ and what "is not historical" with "what is unchanging”. ${ }^{65}$ Indeed it is because of the tendency in Greek thought to deny that knowledge of the transitory is possible that Collingwood finds the creation of historical inquiry by Herodotus "remarkable". ${ }^{66}$ We find this form of history in Collingwood's plaudits for recent French thought, ${ }^{67}$ and for Vico. ${ }^{68}$ Process also features heavily in The Principles of History, where "This is the principle of history, in the wider sense of that word; where

61 Collingwood, Principles of History, 204-208, 244; Collingwood, Idea of History, 83.

${ }^{62}$ Collingwood, Idea of History, 121-122, 84-85, 104. See also van der Dussen, “Collingwood and the Idea of Progress.”

${ }^{63}$ Collingwood, Idea of History, 14-25, 34.

${ }^{64}$ Collingwood, Idea of History, 42.

${ }^{65}$ Collingwood, Idea of History, 42. See also 20, 22, 48-49, 5052, 80, 99-103, 130, 169, 170-208, 184, 359-425.

${ }^{66}$ Collingwood, Idea of History, 20-21.

${ }^{67}$ Collingwood, Idea of History, 184, 189.

${ }^{68}$ Collingwood, Idea of History, 65 (emphasis added). 
history means process in time"; 69 "History is a process which, as it goes on in time, creates its own vehicles ... and the history of anything is the history of the ways in which that thing itself changes."70 It appears in "Notes Towards a Metaphysic”, where "in general, history is development: I mean, a process in which the form as well as the matter changes, namely becomes itself”; ${ }^{71}$ and it even crops up in The New Leviathan, where "all history consists of changes", ${ }^{72}$ where "in the life of mind there are no states, there are only processes”, ${ }^{73}$ and where (strikingly) "the initial and terminal points of change are not facts (only phases of the change are facts); they are abstractions from the fact of change."74

Of course for Collingwood it is only certain kinds of process that history should concern itself with—namely, actions with “insides”. ${ }^{75}$ But Collingwood's interest in Bergson, Alexander, and Whitehead pertains to the experience of process as such. ${ }^{76}$ Bergson's contribution to the theory of history, for

${ }^{69}$ Collingwood, Principles of History, 178.

${ }^{70}$ Collingwood, Principles of History, 251-252.

${ }^{71}$ Collingwood, Principles of History, 127.

${ }^{72}$ Collingwood, New Leviathan, 200.

${ }^{73}$ Collingwood, New Leviathan, 285.

${ }^{74}$ Collingwood, New Leviathan, 241 (emphasis added).

${ }^{75}$ Collingwood, Idea of History, 118.

${ }^{76}$ See Collingwood, Idea of History, 211; Principles of History, 
Collingwood, lies in his analysis of the individual's experience of what we call "history" when we do not mean the rational process of historical knowledge construction or the assertion of facts, but just history happening around us and to us: the kind of "history" in which past and present interpenetrate in our experience. ${ }^{77}$ A philosophy of history in this distinct sense as process would deal with what Collingwood says was the subject of his essay Libellus de Generatione: "primarily a study of the nature and implications of process or becoming ... an attack on 'realism,' showing how the non possumus of 'realists' towards a theory of history arose from their refusal to admit the reality of becoming."78

\section{OVERLAP}

Before fitting all this into Collingwood's philosophical method, let us survey the components. The meaning of "history” in

Collingwood's work takes three distinct forms: ${ }^{79}$

56, 185, 170-171, 251 n.1.

${ }^{77}$ Collingwood, Idea of History, 187-188.

${ }^{78}$ Collingwood, Autobiography, 99 (emphasis added).

${ }^{79}$ This is a provisional minimum. Other readers might add further forms, so long as they are truly distinct. Margit Hurup Grove has also suggested that other forms that might be considered distinct are (4) history as a product of work for public consumption, and (5) history as past ideas to be 
1. history as "the assertion of fact";

2. history as process; and

3. history as a type of (scientific) inquiry. (This is the "highest" or "fullest” form.)

Conceptually, Collingwood's combination of these forms is quite straightforward, such that he does in fact attempt to capture all three in summary definitions of history-as in The Idea of History, where he writes, "History is [3] a science of human action: what the historian puts before himself is [1] things that men have done in the past, and these belong to [2] a world of change." 80 This is probably the closest thing we get from Collingwood to a short statement of the "generic essence" of history. ${ }^{81}$ Sometimes however Collingwood's summary definitions include two forms, but leave out the other, as reconciled and incorporated into the present. Certainly these ideas of history should be accommodated in a putatively comprehensive account of Collingwood's philosophy of history. In conversation [details removed for peer review] ${ }^{80}$ Collingwood, Idea of History, 20.

${ }^{81}$ An earlier attempt, in “The Philosophy of History” (1930), is noticeably rougher: "History is knowledge of the past, and the past consists of events that have finished happening." Collingwood, Essays in the Philosophy of History, 136. 
elsewhere in The Idea of History: "history must have these two characteristics: first it must be about [2] what is transitory, and secondly it must be [3] scientific or demonstrative."82

These three distinct forms combine to produce concepts that are crucial to philosophical understanding of history. The first and second forms, "the assertion of fact" and "history as process”, combine to define the form of history's “subjectmatter": namely, unique processes of a certain kind which are asserted as having happened, or as really happening. Res gestae are concrete facts that are [3] constructed by an intellectual process of abstraction from certain types of [2] process, and which are then [1] asserted. Without the first form, the subjectmatter of history would be processes alone, which need not be asserted as factual, or indeed asserted at all, merely experienced, as for Bergson. And without the second form, the subject-matter of history would be individual facts or states of affairs at points in time, which could be asserted separately, but not narrated as a process by which one becomes another. ${ }^{83}$ So Collingwood's conception of the subject-matter of history combines these two necessary but nevertheless distinct forms: [1] facts in their concrete individuality, ("abstract

${ }^{82}$ Collingwood, Idea of History, 21. There may of course be a rhetorical or pedagogical reason for this formulation, which is taken from a lecture on Greek thought.

${ }^{83}$ See Collingwood, Principles of History, 183. 
individualities" ${ }^{84}$ ), and [2] the processes from which they are abstracted. $^{85}$

So it seems that the third form, history as inquiry, does not (as van der Dussen thinks) replace the assertion of fact (the first form), but supplements and qualifies it, because historical inquiries do not take inquiry itself as their object (or objective): they have the assertion of fact as their object. History still asserts individual facts in Collingwood's thinking from 1925/26 onwards, but now it is the process culminating in the assertion that is in Collingwood's sights. The emphasis now falls not on the "moment" of asserting a fact, but on the process leading to it, the historical method of question and answer. ${ }^{86}$ Collingwood had not however ignored this anyway: in Speculum Mentis he refers to it as "history in the special sense of the word," ${ }^{\text {"7 }}$ and criticises the historian who "thinks that there is any way of determining a fact except by straightforward historical inquiry."88

And finally, the second and third forms, "history as process” and history as inquiry, overlap as (a) the process of inquiry, from which the moment of fact assertion is in fact

${ }^{84}$ Collingwood, Principles of History, 137.

${ }^{85}$ Collingwood, New Leviathan, 241, 285.

${ }^{86}$ Collingwood, Idea of History, 14.

${ }^{87}$ Collingwood, Speculum Mentis, 203.

${ }^{88}$ Collingwood, Speculum Mentis, 211. 
abstracted; as (b) and the object that the historian correctly pursues: namely, a process of thought; and specifically as (c) the assertion that describes the specific process by which one thing becomes another.

The scale of forms proposed here is different from those discussed by Rubinoff and Goldstein, but not (I think) incompatible. For Goldstein, the forms in question are all of those conceptions detailed in The Idea of History, while for Rubinoff the forms are "levels" of experience, ${ }^{89}$ distinguished by the attitude of historical consciousness towards its object. Rubinoff means something altogether more complex than I intend here, mixing in different forms of philosophy as well, or, as he calls it, a "tripartite analysis of consciousness". ${ }^{90}$ So in the first form, the object is assumed to be independently existing; the second form involves an attitude of relativism; and in the third form the historical consciousness operates in full awareness of its own presuppositions. The differences between my account and Rubinoff's originate in my attention to the different definitions given to history in Collingwood's writings, and attention to how they can be reconciled, whereas Rubinoff's purpose is much broader than this. His “levels” refer to first-, second-, and third-order thinking about the forms of history, about the principle of idiography, for instance, rather

\footnotetext{
${ }^{89}$ Rubinoff, 29, 132-133.

${ }^{90}$ Rubinoff, 378 n. 43; for a summary see also 371-372.
} 
than thinking according to the principle itself. The

philosophical "second-order” thought about a thought is a

moment wherein a form of history becomes better defined; it

does not itself constitute a new form of history. ${ }^{91}$

\section{CRITICAL POINTS}

The "lower and vaguer" forms of history, then, are discussed in Parts I to III of The Idea of History, as Leon Goldstein speculated nearly thirty years ago. ${ }^{92}$ But contrary to Goldstein’s reading, the forms of history and the stages of human thought as Collingwood narrates them in The Idea of History do not appear to be coterminous. He does not present logical priority as chronological priority; that is, he does not claim that the first form is established earliest, then incorporated into the second form later, and both then incorporated into the third and highest. Rather, Collingwood finds all three forms of history already roughly realized among the ancients: the two lower

${ }^{91}$ Rubinoff has also proposed an interpretation of Collingwood's philosophy of religion as a scale of forms: Lionel Rubinoff (ed.), Faith and Reason: Essays in the Philosophy of Religion by R. G. Collingwood (Chicago: Quadrangle, 1968), 93-107. On “orders” of thought see also Connelly, 60-61.

${ }^{92}$ Goldstein, 43; see however also 50. 
forms in "theocratic history" and in "myth". ${ }^{93}$ But ancient thought also evinces features of "scientific" historical inquiry, such as "research", ${ }^{94}$ the critical attitude to evidence, ${ }^{95}$ and historians choosing their subjects (rather than allowing subjects to choose them). ${ }^{96}$ By recognizing history as a special type of research, Polybius refines this higher form. ${ }^{97}$ The practical value of research is established even earlier in the Greek conception of historical doxa. ${ }^{98}$

A further correction to Goldstein's account is that not everything described in The Idea of History should have a place in the scale of forms of history. For Collingwood, only philosophically “progressive” elements ${ }^{99}$ are reincorporated in higher forms. But there are also "retrograde” elements ${ }^{100}$ in past thought about the nature of history which are not lower forms, but intrusions. They are the "limitations" of a particular

${ }^{93}$ Collingwood, Idea of History, 14-15; see also Collingwood, Speculum Mentis, 209, and Collingwood, Principles of History, 44.

${ }^{94}$ Collingwood, Idea of History, 18-19.

${ }^{95}$ Collingwood, Idea of History, 25; see also 62.

${ }^{96}$ Collingwood, Idea of History, 27.

${ }^{97}$ Collingwood, Idea of History, 35.

${ }^{98}$ Collingwood, Idea of History, 22-3, 35.

${ }^{99}$ Collingwood, Idea of History, 135.

${ }^{100}$ Collingwood, Idea of History, 135. 
misconception of historical method, ${ }^{101}$ such as elements or presuppositions that are legendary, mythological, theocratic ${ }^{102}$ or theocentric, ${ }^{103}$ eschatological (or futurological), ${ }^{104}$ psychological, ${ }^{105}$ deterministic or positivistic, ${ }^{106}$ substantialistic, ${ }^{107}$ polemical, ${ }^{108}$ cyclical, ${ }^{109}$ probabilistic or possibilistic, ${ }^{110}$ and, importantly, “realistic”-that is, containing the presupposition that the knowing makes no difference to what is known. ${ }^{111}$ Other mistakes about the nature of history include the "scissors and paste" method, the conflation of natural with historical processes, ${ }^{112}$ and the conflation of history and memory. ${ }^{113}$ Although such elements are dealt with

${ }^{101}$ Collingwood, Idea of History, 25-8, 32.

${ }^{102}$ Collingwood, Idea of History, 18.

${ }^{103}$ Collingwood, Idea of History, 55.

${ }^{104}$ Collingwood, Idea of History, 54.

${ }^{105}$ Collingwood, Idea of History, 29-30, 92, 173.

${ }^{106}$ Collingwood, Idea of History, 30-1.

${ }^{107}$ Collingwood, Idea of History, 42-45, 81-85.

${ }^{108}$ Collingwood, Idea of History, 77.

109 Collingwood, Essays in the Philosophy of History, 57-89, 130.

${ }^{110}$ Collingwood, Idea of History, 204.

${ }^{111}$ Collingwood, Idea of History, 142.

${ }^{112}$ Collingwood, Idea of History, 93-133.

${ }^{113}$ Collingwood, Essays in the Philosophy of History, 126-127. 
at length in The Idea of History, they do not belong to the true scale of forms of history. They should in fact be completely discarded, while the philosophically valuable elements that survive coalesce as the forms identified above, as they are always expressions of (1) “fact as such”, of (2) process, or of (3) historical inquiry.

It follows, since all three forms of history are established early on, that we cannot expect the "critical points" that mark the transition from one form to the next to appear in an order that is both logical and chronological. These critical points in fact appear in several variants in The Idea of History, and in an order which is determined only by the thinkers who happen to identify and tackle them. But despite the chronological disorder in which these "critical points" arise, they are I think recognizably crises (as I will call them for simplicity) of the same three forms.

The assertion of fact in crisis

The first form of history_- "the assertion of fact”, "making statements about the past” about actions with "definite places in a time series" ${ }^{\prime 14}$ — which seems to establish individual facts as part of the definition of history, rather than abstract laws, Collingwood identifies, as we have seen, early in The Idea of History, in theocratic history and myth. But the crisis of this

${ }^{114}$ Collingwood, Idea of History, 14. 
first form of history he narrates much later, and in several variants from Positivism to Spengler. Each time the crisis is brought about by the "cutting up" of phenomena into separate facts and falsely isolating them. Consequently "microscopic problems” abound: ${ }^{115}$ Bury finds the historical process contingent and unintelligible, ${ }^{116}$ and Windelband is driven to proclaim a science of the individual per se-even though, Collingwood says, "the whole tradition of European philosophy ... has declared with one voice that this ... is an impossibility”, and one to which Windelband "shows himself strangely blind." 117 The critical point, in short, is that individual facts can be asserted, but there can be no knowledge or understanding of them.

This crisis Collingwood sometimes resolves by recourse to the second form of history, history as process. The problem with Bury is that he "forgets that the historical fact, as it actually exists and as the historian actually knows it, is always a process in which something is changing into something else. This element of process is the life of history." ${ }^{118}$ And to Rickert Collingwood replies that "the essence of history lies not in its

115 Collingwood, Idea of History, 131; see also 143, 156, and 161-162.

${ }^{116}$ Collingwood, Idea of History, 149-151.

${ }^{117}$ Collingwood, Idea of History, 167.

${ }^{118}$ Collingwood, Idea of History, 163. 
consisting of individual facts ... but in the process or

development leading from one to another.”119

But sometimes Collingwood resolves the same crisis by turning to the third form of history, history as inquiry. The question positivism ought to have asked, Collingwood writes, is "How is historical knowledge possible?"120_a move that retraces the transition from history to philosophy in Speculum Mentis, where "The fundamental principle of history itself, namely, the concreteness of the object, thus makes it impossible for the object to ignore the subject, and compels us to recognize an object to which the subject is organic." ${ }^{121}$ Collingwood recognizes the same move in Croce, whose solution to his own variant of the crisis of individual fact led him to the theory of historical judgment. ${ }^{122}$

History as "the assertion of fact", or "fact as such", fails as a definition of history on its own. But individual facts are part of the definition of history. They must however be (re)connected, either to the process from which they are abstracted, or to the mind that is asserting them.

\section{Process in crisis}

${ }^{119}$ Collingwood, Idea of History, 169.

${ }^{120}$ Collingwood, Idea of History, 133.

${ }^{121}$ Collingwood, Speculum Mentis, 244.

${ }^{122}$ Collingwood, Idea of History, 191-195. 
The second form of history, which I have called "history as process", is not fully adequate for Collingwood either: it "falls short ... because the past that is preserved in the present is not a known past." ${ }^{123}$ Like the process of time itself, it is merely experienced. So although Bergson's philosophy and Alexander's conception of "historicity"124 is an important contribution to the theory of history, it must be improved upon, because it describes not knowledge, but only what in Speculum Mentis is described as "an ultimate form of historical thought which is the most rudimentary of all. This is perception ... History is thus, as a specific form of experience, identical with experience.”125

The crisis of history as process, then, is the problem it creates for knowledge, a problem with a history of its own, from ancient Greece ${ }^{126}$ to Bradley ${ }^{127}$ and Bergson. ${ }^{128}$ Collingwood expresses it as a “dilemma,"129 this time between a process which is not natural, but which can only be experienced, not known, and a process which can be known,

${ }^{123}$ Collingwood, Idea of History, 188 (emphasis added).

${ }^{124}$ Collingwood, Idea of History, $210 \mathrm{n}$.

${ }^{125}$ Collingwood, Speculum Mentis, 204-205 (emphasis added).

${ }^{126}$ Collingwood, Idea of History, 20-21.

${ }^{127}$ Collingwood, Idea of History, 141.

${ }^{128}$ Collingwood, Idea of History, 187-190.

${ }^{129}$ Collingwood, Idea of History, 141, 174. 
but is therefore a natural process. Again the solution is to accept neither "horn" of the dilemma, but to escape between them by renewing attention to another form of history. Collingwood identifies this move- the move from history as experience to the idea of knowledge itself-in Oakeshott, in whose work "Bradley’s dilemma is transcended"; ${ }^{130}$ and (fleetingly) in Dilthey. ${ }^{131}$

\section{Historical inquiry in crisis?}

There is no crisis for the third form of history, historical inquiry, since it is the highest form. But there appear to be crises, because of the ease with which historians and philosophers of history misconceive one of the other forms. Apparent crises are caused most commonly, Collingwood thinks, by false presuppositions about the nature of historical facts — which he identifies in "the German movement”, which is "always thinking ... in terms of epistemology."132

At this point it is necessary to deal with the potential obstacle of Speculum Mentis, where Collingwood seems to say that there is a crisis for "history as such"133_ a crisis which

${ }^{130}$ Collingwood, Idea of History, 151-152; see however 158.

${ }^{131}$ Collingwood, Idea of History, 172.

${ }^{132}$ Collingwood, Idea of History, 184.

${ }^{133}$ Collingwood, Speculum Mentis, 246. 
“destroys” it, and causes it to "break down”. ${ }^{134}$ We might bypass this apparent difficulty by simply reading the books separately, on their own merits, and not insist on consistency throughout Collingwood's oeuvre. Or we might disqualify the contents of Speculum Mentis from Collingwood's own authentic philosophy of history. But the former gives ground to one of the "disunity" verdicts outlined above, and the latter ignores the considerable compatibility of most of what is said about history in Speculum Mentis with Collingwood's later or "mature" thought.

Actually Speculum Mentis narrates the breakdown not of the highest form of history, but of the first form of history, which (as we have already seen) he would later narrate again in The Idea of History. The crisis Collingwood describes arises in the realization that the object, the concrete fact as such, is inseparable from historical thinking. ${ }^{135}$ In Speculum Mentis this prompts the transition to philosophy. ${ }^{136}$ But, he writes there, "though in the transition from history to philosophy, history as such is destroyed, the transition is so brief and so inevitable that much belonging to the historical frame of mind is taken over almost unchanged by the philosophical.”137

${ }^{134}$ Collingwood, Speculum Mentis, 231-239.

${ }^{135}$ Collingwood, Speculum Mentis, 244.

${ }^{136}$ Collingwood, Speculum Mentis, 245-246.

${ }^{137}$ Collingwood, Speculum Mentis, 246. 
Speculum Mentis then does not describe a crisis of history that Collingwood later changes his mind about, as van der Dussen thinks. It documents a crisis that arises out of mistaking the highest form of history, history as inquiry, for a lower form, and this rightly prompts a philosophical move for historical thought to better understand itself. Wherever, then, historical inquiry appears to be in crisis, what is in fact happening, for Collingwood, is that it is being mistaken for one of its lower forms.

\section{CONCLUSIONS}

It seems, then, that Collingwood's philosophy of history is indeed compatible with what he says about how philosophy is to be done. There are "forms" of history in Collingwood's thought that are distinct, and which seem to relate as they are supposed to. He even narrates the "critical points" by which one form of history is “replaced” by a higher one: the (1) assertion of individual facts is supplemented and qualified by (2) the connection of individual facts in processes which are passively experienced, which is in turn supplemented and qualified by (3) the active investigation of questions. The accounts of history surveyed in parts I to III of The Idea of History (or at least I to II) are "lower and vaguer" ways of understanding history which, although they comprise something of the truly historical, also contain "retrograde" 
elements which are discarded as higher forms clarify the lower. Where all three forms are present, "history is a kind of research or inquiry"138 — a science in which the conclusions asserted are the facts of a reality that is itself a process. Because this is the highest form of history, it incorporates the two lower forms, and thus provides the most complete description of history as a philosophical concept.

But the sort of "replacement” Collingwood has in mind is only ordered in this way logically. Chronologically, in the real history of philosophy of history, this clarification has operated in a curiously triangular way. All of the three forms are present in ancient thought, albeit mixed with non-historical elements which are gradually eradicated. Advances in philosophy of history are achieved for Collingwood when reflection on one form generates a critical point, or dilemma, which is then resolved when thought moves across to either of the other two forms of history and resolves the problem from there.

It follows that the possible verdicts outlined above cannot be drawn: Collingwood does not abandon the scale of forms thesis he had prescribed in An Essay on Philosophical Method, and his later philosophy of history is not impaired by its absence. It is also not the case that Collingwood must have come to regret the account of history given in Speculum Mentis,

${ }^{138}$ Collingwood, Idea of History, 9. 
as van der Dussen thinks. But although Collingwood's later thought seems to clarify rather than cancel his earlier thought, it is not necessarily true either that the "plan or architectonic" of his later thought is already laid out in Speculum Mentis, as Rubinoff thinks. ${ }^{139}$ As for the question of the "generic essence" of history, I see no reason to correct Goldstein's view that Collingwood does not offer a statement of it—if it is right to assume that such a statement should be distinct from his philosophy of history taken as a whole. But it is perhaps anyway excessive to demand such a "generic" statement. Just because the highest form of history is stated and analysed in Collingwood's work, it does not follow that the work of philosophers of history is done. That history is a kind of inquiry was, after all, realized roughly by the ancients.

Department of Politics

University of Hull

Hull

HU6 7RX

United Kingdom

C.Fear@hull.ac.uk

(+44) 7531558085

139 Rubinoff, 31. 
Number of words: 7,592

\section{ACKNOWLEDGEMENTS}

For detailed comments on research leading to this article, thanks are due to David Boucher and James Connelly. For helpful observations and suggestions on a conference paper version, thanks are also owed to Teresa Smith, Margit Hurup Grove, and Howard Williams. 